\title{
Occupational asthma caused by bacillary amylase used in the detergent industry
}

\author{
A M Hole, A Draper, G Jolliffe, P Cullinan, M Jones, A J Newman Taylor
}

\begin{abstract}
Four cases are reported of occupational asthma due to amylase derived from Bacillus licheniformis, used in detergent washing powders. It is thought that these are the first reported cases of asthma due to this enzyme in the detergent industry. All four employees (men) were from the same factory and none had a history of asthma or atopy. All developed symptoms of wheeze at work after an initial symptom free period. Symptoms improved during periods away from work. All undertook serial peak flow recordings (not diagnostic) and underwent skin prick tests, radio allergosorbent test (RAST) measurement, and specific bronchial provocation testing. The bronchial provocation testing was performed by a dust tipping method in a single blind manner, with lactose as an inert control and powdered amylase, provided by the employer, as an active agent. Serial measurements of forced expiratory volume in 1 second $\left(F E V_{1}\right)$ were recorded and histamine provocative concentration causing a $20 \%$ fall in $\mathrm{FEV}_{1}\left(\mathbf{P C}_{20}\right)$ tests were determined before and 24 hours after each challenge. Patient 1 developed an isolated early reaction, patient 2 an isolated late reaction, and patients 3 and 4 developed dual reactions. All showed an increased non-specific bronchial responsiveness after active challenge. The introduction of encapsulated enzymes in the detergent industry was followed by a reduction in the incidence of respiratory sensitisation. These patients developed occupational asthma despite working only with encapsulated enzymes. This highlights the importance of careful surveillance after the introduction of new agents in the workplace.

(Occup Environ Med 2000;57:840-842)
\end{abstract}

Keywords: occupational asthma; detergent enzyme; amylase

The practice of adding enzymes to washing powders to improve their cleaning capability began in the mid-1960s. The introduction of powdered protease, derived from Bacillus subtillis, was followed by high rates of asthma associated with immunoglobulin $\mathrm{E}$ ( $\mathrm{IgE}$ ) among factory workers ${ }^{1-3}$ and several cases of enzyme allergy among consumers. As a result most manufacturers removed proteases from their products until the development of enzyme encapsulation in the 1970 s.

During the past 10 years, as well as proteases, enzymes of other specificities, generally encapsulated, have been added to detergent powders: these include amylase derived from Bacillus licheniformis, cellulase, and lipase. There are no published reports of occupational asthma in detergent workers attributable to these enzymes, although amylase derived from Aspergillus oryzae, which is immunologically distinct from the bacterial amylase used in detergents, is an important cause of occupational asthma among bakers who use it in a powdered form as a flour improver. ${ }^{4}$

The four cases reported in this paper are all men who worked in the production or packing processes at a single detergent powder factory. The factory opened in 1985 and has used encapsulated protease enzymes since then. In 1990 and 1996 respectively, encapsulated amylase and cellulase were introduced. Since 1995 detergents containing higher concentrations of enzymes, particularly amylase, have been manufactured.

\section{Case reports}

SYMPTOMS

All four of the men had worked with each enzyme type. None had a previous history of asthma, eczema, or hay fever. Three described work related rhinitis first occurring 18 months to 2 years after starting work in the factory (table). The fourth (patient 1) described rhinitis developing after 5 years of working with protease and 1 year with amylase. All four developed chest tightness and wheeze between 2 or 3 years later, which improved away from work. Two years after the onset of his chest symptoms, patient 1 was prescribed inhaled steroids and terbutaline which provided only partial improvement.

\section{IMMUNOLOGICAL TESTING}

None had immediate skin prick test reactions elicited by common aeroallergens (cat dander, grass pollen, and Dermatophagoides pteronyssinus; Allergopharma, Reinbeck, Germany). All had immediate responses $(>3 \mathrm{~mm})$ to one or more enzyme solutions $(1 \mathrm{mg} / \mathrm{ml})$. Amylase provoked a response in all four, three patients 
Table 1 Patients: atopy, first exposure to enzymes, initiation of symptoms, and immunological findings

\begin{tabular}{|c|c|c|c|c|c|c|c|}
\hline Patient No & Age & Atopic & $\begin{array}{l}\text { First exposure to } \\
\text { detergent enzymes }\end{array}$ & $\begin{array}{l}\text { Symptoms } \\
\text { began }\end{array}$ & Enzyme & $\begin{array}{l}\text { Skin prick test } \\
(\text { size, } \mathrm{mm})\end{array}$ & $\begin{array}{l}\text { RAST \% } \\
\text { binding }\end{array}$ \\
\hline \multirow[t]{3}{*}{1} & \multirow[t]{3}{*}{48} & \multirow[t]{3}{*}{ No } & \multirow[t]{3}{*}{1985} & \multirow[t]{3}{*}{$1990-1$} & Amylase & 14 & 35 \\
\hline & & & & & Protease & 8 & 60 \\
\hline & & & & & Cellulase & 7.5 & 15 \\
\hline \multirow[t]{3}{*}{2} & \multirow[t]{3}{*}{42} & \multirow[t]{3}{*}{ No } & \multirow[t]{3}{*}{1995} & \multirow[t]{3}{*}{1996} & Amylase & 6 & 77 \\
\hline & & & & & Protease & 0 & 7 \\
\hline & & & & & Cellulase & 3 & 28 \\
\hline \multirow[t]{3}{*}{3} & \multirow[t]{3}{*}{27} & \multirow[t]{3}{*}{ No } & \multirow[t]{3}{*}{1993} & \multirow[t]{3}{*}{1995} & Amylase & 7.5 & 59 \\
\hline & & & & & Protease & 4 & 41 \\
\hline & & & & & Cellulase & 4.5 & 50 \\
\hline \multirow[t]{3}{*}{4} & \multirow[t]{3}{*}{28} & \multirow[t]{3}{*}{ No } & \multirow[t]{3}{*}{1992} & \multirow[t]{3}{*}{1993} & Amylase & 6.5 & 74 \\
\hline & & & & & Protease & 7 & 37 \\
\hline & & & & & Cellulase & 0 & 1 \\
\hline
\end{tabular}

RAST=radioallergosorbent test.

$(1,3$, and 4$)$ had responses to protease, and three $(1,2$, and 3$)$ to cellulase.

With RAST and the same enzymes, we found high concentrations of circulating IgE antibodies to amylase and protease in all four men, and to cellulase in three.

BRONCHIAL PROVOCATION TESTING (figure) Serial peak flow measurements were either not feasible or were not diagnostic in any case. We therefore undertook specific inhalation testing to make a diagnosis. Before admission the patients stopped all anti-inflammatory asthmatic treatment. Inhalation testing was carried out within 12 weeks of occupational exposure to detergent enzymes. A dust tipping method was used, with granulated enzymes (provided by the factory) crushed by hand with a pestle and mortar. With lactose as an inert control, we conducted the tests in a single blind manner.
Forced expiratory volume in 1 second $\left(\mathrm{FEV}_{1}\right)$ was measured every 5-10 minutes for 1 hour after the test and subsequently for 24 hours at hourly intervals while the patient was awake. The $\mathrm{FEV}_{1}$ response to inhaled histamine was measured before and 24 hours after each test with the Cockroft method. ${ }^{5}$ Results were expressed as histamine $\mathrm{PC}_{20}$

None of the men reacted to the inert control but in each case the first exposure to amylase reproduced nasal symptoms similar to those experienced at work, which in the case of patient 2 was severe and occurred within 5 minutes of the test exposure. Amylase provoked an asthmatic response in all four: patients 1,3, and 4 had a dual response; patient 2 developed an isolated late reaction, which began 6 hours after exposure. In all cases the asthmatic responses were associated with a fall in histamine $\mathrm{PC}_{20}$.

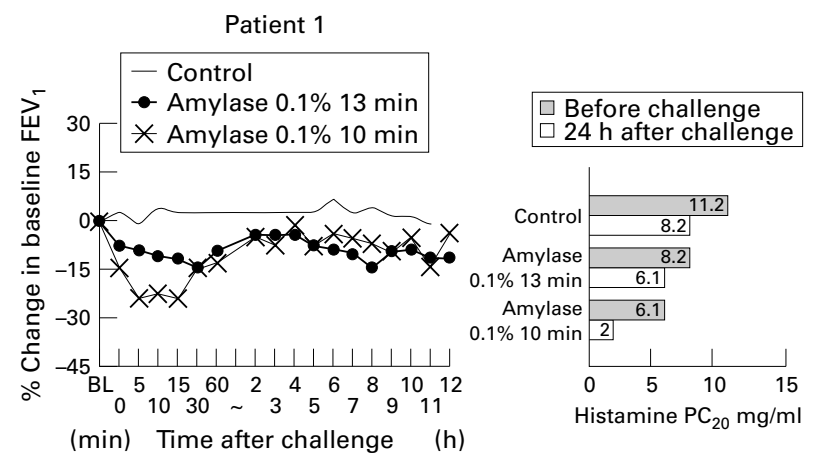

Baseline $\mathrm{FEV}_{1} 3.05$

Patient 3

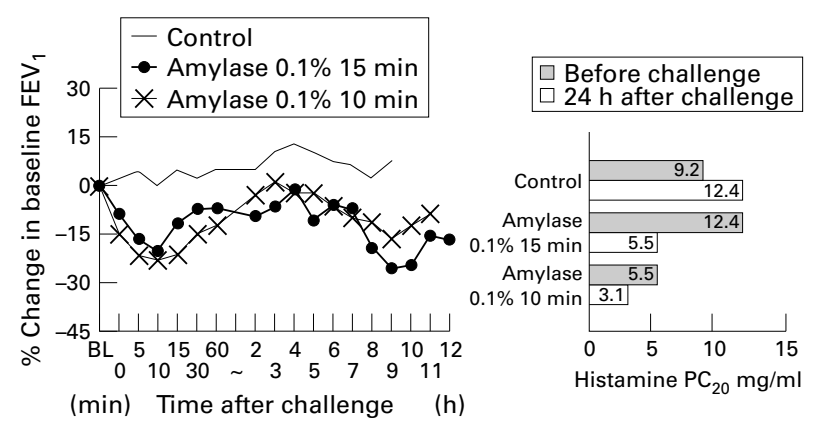

Baseline FEV 13.93

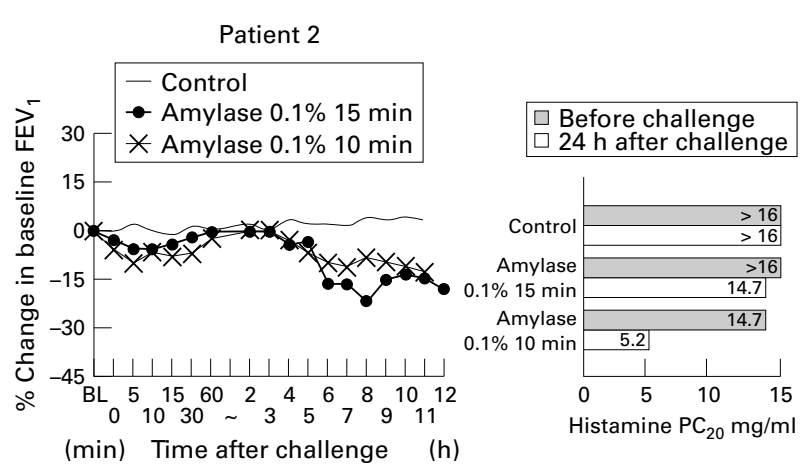

Baseline $\mathrm{FEV}_{1} 3.9$

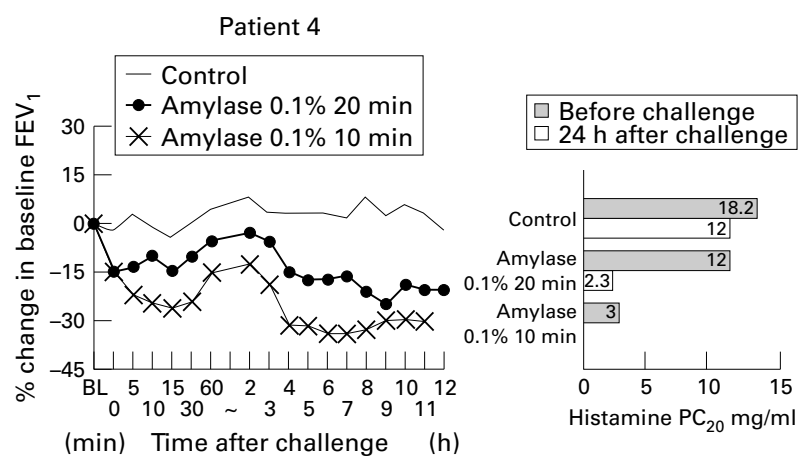

Baseline FEV 13.82

Changes in baseline FEV $V_{1}$ in the four patients. 
Patient 1 was also tested with protease which provoked a dual asthmatic response and associated fall in his $\mathrm{PC}_{20}$. Cellulase provoked an immediate nasal and mild asthmatic response but no reduction in histamine $\mathrm{PC}_{20}$.

\section{Discussion}

We think that these are the first reported cases of occupational asthma in detergent manufacturers caused by allergy to bacterial amylase, demonstrated by specific inhalation testing. The cases reported are four of a large outbreak of asthma in a modern detergent factory incorporating encapsulated protease, amylase, and cellulase into detergents.

Fungal amylase, well recognised as a cause of asthma in bakers, is used as a dough improver in powdered form. Bacterial amylase derived from Bacillus Licheniformis which is immunologically distinct from fungal amylase, was used in the factory in which these men worked, encapsulated in granules.

Animal studies ${ }^{6}$ have suggested that bacterial amylase is a more potent allergen than protease, its allergenicity potentiated by concurrent inhalation of protease. ${ }^{7}$ Modern en- zyme detergents often contain a mixture of enzymes, which usually include a protease and bacterial amylase. Exposure to both enzymes is likely to become increasingly common among those working in the detergent industry, increasing the risk of allergy to amylase and associated asthma in the absence of appropriate preventive measures.

1 Flindt MLH. Pulmonary disease due to inhalation of derivatives of Bacillus subtilis containing proteolytic enzyme. Lancet 1969;i:1177-81

2 Newhouse ML, Tagg B, Pocock SJ, et al. An epidemiological study of workers producing enzyme washing powders. Lancet. 1970;i:689-93.

3 Greenberg M, Milne JF, Watt A. Survey of workers exposed to dusts containing derivatives of Bacillus subtilis. $B M \mathcal{F}$ 1970;ii:629.

4 Brisman J, Belin L. Clinical and immunological responses to occupational exposure to $\alpha$-amylase in the baking industry. Br F Ind Med 1991;48:604-8.

5 Cockroft DW, Killian DN, Mellon JJA, et al. Bronchial reactivity to inhaled histamine: a method and clinical survey. tivity to inhaled histamine: a met
Clinical Allergy 1977;7:235-43.

6 Sarlo K, Fletcher ER, Gaines WG, et al. Respiratory allergenicity of detergent enzymes in the guinea pig intra racheal test: association with sensitization of exposed individuals. Fundam Appl Toxicol 1997:39:44-52.

7 Sarlo K, Ritz HL, Fletcher R, et al. Proteolytic detergent enzymes enhance the allergic antibody responses of guinea pigs to nonproteolytic detergent enzymes in a mixture: implication for occupational exposure. F Allergy Clin Immunol 1997;100:480-7. 